\title{
Institutionalization of REDD+ MRV in Indonesia, Peru, and Tanzania: progress and implications
}

\author{
$\underline{\text { Robert M. Ochieng }}^{1}, \underline{\text { Bas Arts }}^{1}, \underline{\text { Maria Brockhaus }}^{2}{ }^{2}$ and Ingrid J. Visseren-Hamakers ${ }^{3}$
}

\begin{abstract}
Reducing emissions from deforestation and forest degradation in developing countries (REDD+) has opened up a new global discussion on forest monitoring and carbon accounting in developing countries. We analyze and compare the extent to which the concept of measurement, reporting, and verification (MRV) for REDD+ has become institutionalized in terms of new policy discourses, actors, resources, and rules in Indonesia, Peru, and Tanzania. To do so, we draw on discursive institutionalism and the policy arrangement approach. A qualitative scale that distinguishes between "shallow" institutionalization on the one end, and "deep" institutionalization on the other, is developed to structure the analysis and comparison. Results show that in all countries MRV has become institutionalized in new or revised aims, scope, and strategies for forest monitoring, and development of new agencies and mobilization of new actors and resources. New legislations to anchor forest monitoring in law and procedures to institutionalize the roles of the various agencies are being developed. Nevertheless, the extent to which MRV has been institutionalized varies across countries, with Indonesia experiencing "deep" institutionalization, Peru "shallow-intermediate" institutionalization, and Tanzania "intermediate-deep" institutionalization. We explore possible reasons for and consequences of differences in extent of institutionalization of MRV across countries.
\end{abstract}

Key Words: discursive institutionalism; Indonesia; institutionalization; Peru; policy arrangement approach; REDD+ MRV; Tanzania

\section{INTRODUCTION}

National forest monitoring is becoming an established activity in developing countries. Since the postcolonial era, many developing countries have monitored and reported on the status and extent of their forests (FAO 1993, McRoberts and Tomppo 2007, Freitas et al. 2010, Lei et al. 2010, Tomppo et al. 2010a, Lund [date unknown]). Although initially focused on timber stocks, forest monitoring in both developed and developing countries have evolved to include measurement of other variables such as forest health and vitality (Mohren et al. 2012, Lund [date unknown]), largely in response to the paradigm shift from "mono-functional" to "multifunctional" forestry. These changing demands have provided challenges for both developed and developing countries. However, the United Nations Framework Convention on Climate Change (UNFCCC) decision on reducing emissions from deforestation and forest degradation, and the role of conservation, sustainable management of forests, and enhancement of forest carbon stocks in developing countries (REDD+) has opened up new discussions on forest monitoring in developing countries. Specifically, discussions on monitoring, reporting, and verification (MRV) of REDD+ outcomes introduces new ideas on forest monitoring in developing countries regarding "what" to measure, by "whom," and using "which" technologies (UNFCCC 2009).

The emergence of international discussions on MRV not only presupposes that existing institutions for forest monitoring in developing countries are inadequate but also presents challenges on how to develop new or strengthen existing institutions for forest monitoring in these countries. These institutions can be conceived of as ideas and discourses that are expressed through regulatory arrangements such as laws and standards (Arts and Leroy 2006, Schmidt 2008). Several studies have highlighted that majority of REDD+ countries have low technical and institutional capacity to measure and report on their forests in a manner that meets international standards (Holmgren and Marklund 2007, Holmgren et al. 2007, Grainger and Obersteiner 2011, Romijn et al. 2012, Romijn et al. 2015, Ochieng et al. 2016a). Others, while pointing at the large and varying technical capacity gaps (Romijn et al. 2012), also show that progress is being made in some countries (Korhonen-Kurki et al. 2013, Minang et al. 2014, Robiglio et al. 2014, Ochieng et al. 2015), suggesting that institutions for forest monitoring in developing countries are adapting to accommodate the new demands. These studies thus provide arguments for an emerging discourse that highlight the need for institutional change while indicating countries' capacity to conduct forest monitoring for REDD+.

To date, however, few studies have examined how the demands presented by international agreements on MRV have reshaped institutions for forest monitoring in REDD+ countries. Although some studies (Korhonen-Kurki et al. 2013, Minang et al. 2014, Robiglio et al. 2014, Ochieng et al. 2015) have examined the development of strategies and agencies to implement MRV in selected REDD+ countries, a comprehensive comparative analysis of the extent of institutionalization of MRV across countries is lacking. We aim to fill this gap by comparing the extent of institutionalization of MRV in Indonesia, Peru, and Tanzania. To do so, we address two questions: (1) How and to what extent has MRV become institutionalized in new or reformed institutions for forest monitoring in Indonesia, Peru, and Tanzania?; (2) How can differences in extent of institutionalization of MRV in these countries be explained? Addressing these questions is relevant in two ways. First, examining the extent to which MRV has become institutionalized in new or reformed institutions for forest monitoring in a given country indicates that

${ }^{1}$ Forest and Nature Conservation Policy Group, Wageningen University and Research Centre, ${ }^{2}$ Department of Forest Sciences, University of Helsinki, ${ }^{3}$ Department of Environmental Science and Policy, George Mason University 
country's progress in implementing MRV. Second, assessing the relevance of factors for discourse institutionalization in explaining the extent of institutionalization of MRV in different countries offers useful lessons to inform institutionalization of MRV in other countries. The latter also contributes to the empirical assessment of these factors in explaining institutionalization. This is an aspect that is underrepresented in the discursive institutionalist literature.

We draw on the theoretical claims of discursive institutionalism (Schmidt 2008, Arts and Buizer 2009), namely that new ideas, and the discourses through which they are generated and deliberated may reshape and materialize in institutions. We address the first question by examining the strategies that have been developed to implement MRV, the actors and resources that have been mobilized, and the rules that have been developed to anchor MRV in regulatory arrangements in each country. We address the second question by reflecting on the factors that must be present for any discourse to institutionalize, and their manifestation in each country to explain any differences across the countries. We begin by introducing the theoretical framework of discursive institutionalism and, explain how discourse institutionalization can be examined using the policy arrangement approach (Arts and Tatenhove 2004, Arts and Leroy 2006). After describing the methods used, we present the results in two steps. We first examine the extent of institutionalization of MRV in each country; and then explore the factors for the varied extent of institutionalization. We conclude by discussing the results and drawing lessons to inform institutionalization of MRV in other countries.

\section{THEORETICAL FRAMEWORK: DISCURSIVE INSTITUTIONALISM}

We use discursive institutionalism (DI) as our theoretical framework. DI's main assumption is that new discourses and the ideas they represent may undermine or reshape existing institutions and thereby cause institutional change (Schmidt 2008, Arts and Buizer 2009, Schmidt 2010). DI has been used in various fields to analyze how new ideas and the discourses through which they are generated and exchanged influence institutions. Buijs et al. (2014), for example, show how counter discourses and ideas on Dutch nature policy undermined existing institutions and materialized in new ones for nature conservation in the Netherlands. At a global level, Arts and Buizer (2009) show how new discourses and ideas, for example on sustainability and biodiversity, have emerged and materialized in several new institutions for global forest governance over the last decades. On REDD+ specifically, den Besten et al. (2014) show how new discourses and ideas on deforestation and forest degradation shaped international policy discussions and strategies to reduce greenhouse gas (GHG) emissions and mitigate climate change, and materialized in several institutions to guide REDD+ implementation.

Analytically, DI distinguishes between discourses and institutions. Discourses are conceived as shared and at the same time contested ideas about public aims and policies, and as the interactive processes of politics and policy making. Given its double-view of discourses, a discursive institutionalist perspective allows us to simultaneously indicate the ideas represented in a discourse and the interactive processes by which these ideas are discussed during public deliberations and policy making. Institutions, on the other hand, are seen as discourses and ideas that are expressed through regulatory arrangements such as laws and standards. Although DI considers ideas and discourses as one of the triggers of institutional change, it does not in our view explicate what institutional change entails. Similarly, although DI posits that discourses and ideas, when successful, may institutionalize, it does not elucidate what institutionalization actually entails. Therefore to conceptualize institutionalization and institutional change, we use the policy arrangement approach (Van Tatenhove et al. 2000, Arts and Leroy 2006).

A policy arrangement approach (PAA) examines the way a certain policy domain such as national forest monitoring is shaped in terms of policy discourses, actors, resources, and rules (Arts and Leroy 2006, Liefferink 2006, Wiering and Arts 2006). Policy discourses are the discursive processes of policy making as discussed above. Such policy discourses can contain different types of ideas, including policies and programs (Schmidt 2008, Mehta 2010). Policy ideas are the strategies proposed by policy makers to achieve public aims. Programmatic ideas encompass the definition of the policy problem at hand and the aims to be achieved (Schmidt and Radaelli 2004, Schmidt 2008, Mehta 2010). Programmatic and policy ideas are here operationalized as aims and scope, and strategies for forest monitoring, respectively. Actors are the stakeholders involved in formulating and implementing policies or influenced by such policies. Resources are the tools, technologies, budgets, and skills that actors can mobilize to achieve their policy aims. Rules, finally, are the legislations and procedures that define the way a policy issue should be conducted. Whereas legislations are the laws enacted to implement policies, procedures delineate division of roles and authority among the actors (Wiering and Arts 2006, Arnouts et al. 2012). The PAA considers institutionalization as the solidification of an idea/discourse into new/revised policy aims and strategies, actor coalitions, resources, and rules of the game (Arts and Buizer 2009, Buijs et al. 2014).

Thus, in our case institutionalization is considered to occur when MRV and its ideas are (1) formed into policy discourses at the national level in terms of new aims, scope, and strategies for forest monitoring, (2) mobilization of new actors and (3) additional resources, and (4) development of new rules to formally anchor MRV and the role of different actors in regulatory arrangements (cf. Alemayehu et al. 2013). To compare the extent of institutionalization of MRV across the three countries, we apply a qualitative scale (Fig. 1) that distinguishes between shallow institutionalization (solidification into only one element of the PAA, e.g., materialization in only new or revised aims and strategies) on one end, and deep institutionalization (solidification into all four elements of the PAA, namely aims and strategies, actors, resources, and rules) on the other (see Wiering and Arts 2006 for more on shallow and deep institutionalization).

Of course, not all (new) ideas and discourses subsequently institutionalize during policy making (Phillips et al. 2004, Schmidt and Radaelli 2004, Schmidt 2008, 2010, Arts and Buizer 2009, Crespy and Schmidt 2014). This observation has led discursive institutionalists to examine the factors necessary for discourse institutionalization. Phillips et al. (2004), for instance, highlight seven factors that must hold in order for new discourses 
Fig. 1. A qualitative scale for assessing extent of institutionalization of REDD+ measurement, reporting, and verification $(\mathrm{MRV})$. PAA = policy arrangement approach.

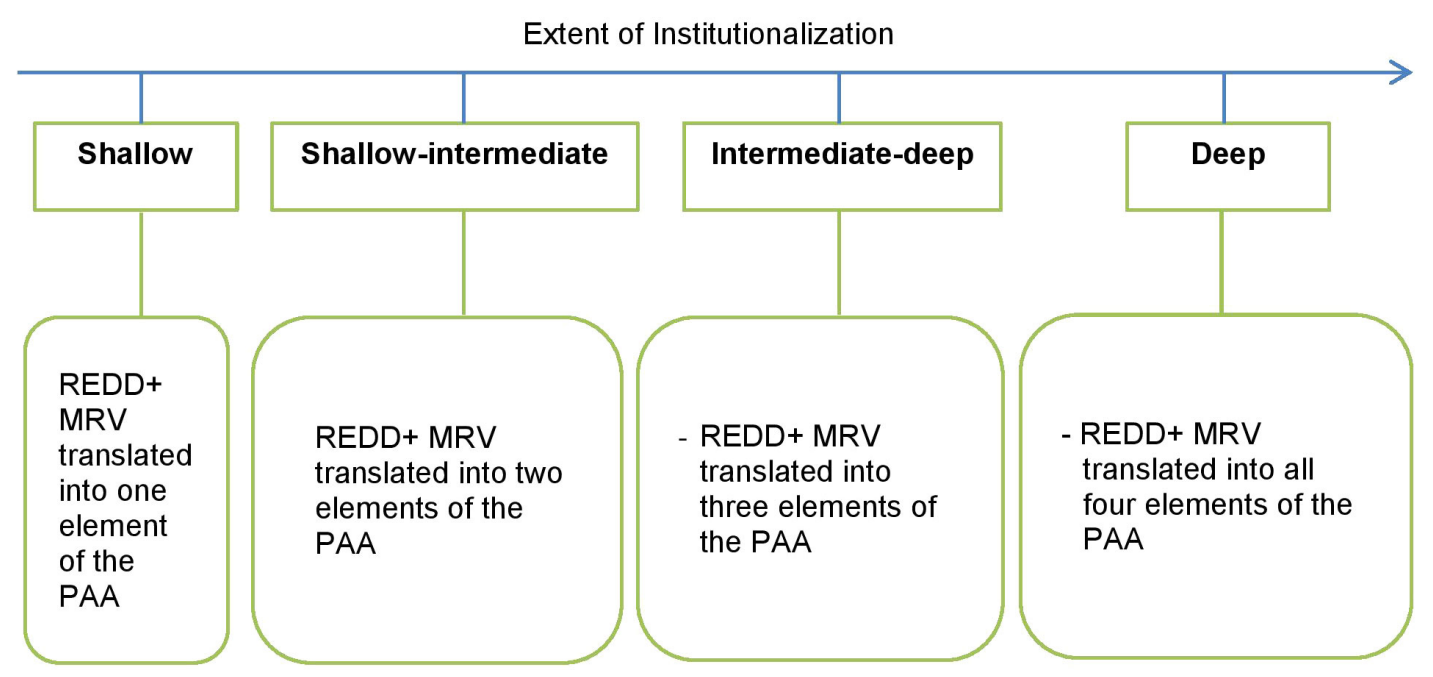

and ideas to institutionalize. Building on the work of Phillips et al. (2004) and others (Schmidt 2008, 2010, Arts and Buizer 2009), Buijs et al. (2014) have condensed these factors into five. These authors hold that for new discourses and ideas to materialize in new institutions (a) the new discourse and ideas must cover existential and timely topics, and resonate with a larger and concerned audience; (b) they must be credible and coherent to that audience; (c) they must be carried and advocated by authoritative and sentient agents; (d) they must take the form of popular genres or storylines, i.e., transcend the language of specific individuals or organizations; and (e) the legitimacy of existing discourse and ideas, and related institutions must be under pressure. We will examine the extent to which each of these factors manifested in the three countries to explain any differences in extent of institutionalization of MRV.

\section{METHODS}

The study was conducted in Indonesia, Peru, and Tanzania, which were selected for two reasons. First, compared to Peru, Indonesia and Tanzania started their REDD+ policy processes at a relatively early stage. Additionally, both countries have been receiving support from Norway's International Forest and Climate Initiative, the UN REDD Program, and the Forest Carbon Partnership Facility (Brockhaus and Di Gregorio 2014) including on issues regarding establishing forest monitoring systems for REDD+ (LTS International 2013). Thus, both can be expected to be well advanced in implementing the different REDD+ elements including MRV. Peru, on the other hand, became actively engaged in REDD+ only after 2012 (Piu and Menton 2014). Second and most importantly, despite the early engagement of Indonesia and Tanzania in REDD+, recent studies show that they are at different stages in developing technical and institutional capacities for MRV (Korhonen-Kurki et al. 2013, LTS International 2013, Minang et al. 2014, Ochieng et al. 2016a).

Primary data were obtained through interviews with representatives of different state and nonstate agencies (Table 1). These representatives were selected because they have been involved in forest monitoring and or in MRV discussions in the respective country, and were selected judgementally and through snowball sampling (Punch 2005). Field work was conducted between October and December 2015 and August and September 2015 in Indonesia and Tanzania, respectively. In Peru, field work was conducted between May and June 2014. In all countries, the data were corroborated through follow-up interviews with a subset of the interviewees in September 2016. Secondary data were obtained through analyses of national REDD+ policy documents, and other scientific and grey literature.

Table 1. Number of interviewees by category by country.

\begin{tabular}{lccc}
\hline \hline Respondent of category & Indonesia & Peru & Tanzania \\
\hline $\begin{array}{l}\text { Governmental agencies (National/ } \\
\text { subnational) }\end{array}$ & 8 & 20 & 9 \\
$\begin{array}{l}\text { Domestic NGOs/Civil Society } \\
\begin{array}{l}\text { Organizations } \\
\text { International/Intergovernmental }\end{array}\end{array}$ & 7 & 6 & 5 \\
$\begin{array}{l}\text { organizations } \\
\text { Others (private, consultants, university) }\end{array}$ & 5 & 5 & 2 \\
Total & 34 & 11 & 7 \\
\hline
\end{tabular}

\section{RESULTS}

\section{Institutionalization of MRV in Indonesia, Peru, and Tanzania}

Deep institutionalization of MRV in Indonesia

As summarized in Table 2 for all countries, the extent of institutionalization of MRV in Indonesia can be assessed as deep because changes can be detected in all the four elements of the PAA. The aims and scope of forest monitoring have been reviewed and expanded to include measurement of forest carbon stocks and its changes (RoI 2011, Sugardiman 2012, Krisnawati et al. 2015a). To realize these expanded aims and scope of forest monitoring, Indonesia has developed and implemented several strategies. One such strategy is the implementation of the 
Table 2. Overview of extent of institutionalization of measurement, reporting, and verification (MRV) in Indonesia, Peru, and Tanzania.

\begin{tabular}{|c|c|c|}
\hline Indonesia & Peru & Tanzania \\
\hline $\begin{array}{l}\text { Aims and Strategies } \\
\text { Policy aims of forest measurement expanded } \\
\text { to include forest carbon stocks and its changes } \\
\text { Strengthening of the National Forest } \\
\text { Monitoring System } \\
\text { Implementation of Indonesian Carbon } \\
\text { Accounting System (INCAS) } \\
\text { Development of standards and methods for } \\
\text { forest carbon monitoring, and remote sensing } \\
\text { (RS) } \\
\text { Development of allometric equations } \\
\text { Piloting provincial/district forest carbon } \\
\text { monitoring } \\
\text { Some strategies, especially INCAS, are } \\
\text { contested }\end{array}$ & $\begin{array}{l}\text { Policy aims of forest measurement expanded } \\
\text { to include forest carbon stocks and its changes } \\
\text { Implementation of multipurpose national } \\
\text { forest inventory } \\
\text { Development annual deforestation statistics } \\
\text { Development of allometric equations for } \\
\text { Amazon region } \\
\text { national forest inventory and development of } \\
\text { emission factors not completed }\end{array}$ & $\begin{array}{l}\text { Policy aims of forest measurement expanded to } \\
\text { include forest carbon stocks and its changes } \\
\text { Implementation of National Forest } \\
\text { Monitoring and Assessment of Tanzania } \\
\text { Mainland and Zanzibar Forest Monitoring } \\
\text { and Assessment completed } \\
\text { Piloting use of LiDAR } \\
\text { Piloting community forest monitoring } \\
\text { Development of region/ species-specific } \\
\text { allometric equations }\end{array}$ \\
\hline Actors & & \\
\hline $\begin{array}{l}\text { Strengthening of Directorate General (DG)- } \\
\text { Planning } \\
\text { Directorate of greenhouse gas (GHG) } \\
\text { Inventory and MRV established } \\
\text { Subdirectorate of GHG Inventory for land- } \\
\text { based section, and } \\
\text { Section for GHG Inventory for Forestry Sector } \\
\text { established }\end{array}$ & $\begin{array}{l}\text { Forest Inventory section established } \\
\text { Technical Task Force for Forest Monitoring } \\
\text { Executive Steering Committee } \\
\text { Intergovernmental Group } \\
\text { National Forest Monitoring Group } \\
\text { Task Force yet to work under one roof } \\
\text { Most other bodies yet to be constituted }\end{array}$ & $\begin{array}{l}\text { National Carbon Monitoring Centre (NCMC) } \\
\text { established } \\
\text { Forest Inventory and Monitoring Section } \\
\text { established at Tanzania Forest Service } \\
\text { Mobilization of Village Environment and } \\
\text { Natural Recourse (NR) committees } \\
\text { Loss of institutional memory due to cessation } \\
\text { of REDD+ pilots }\end{array}$ \\
\hline $\begin{array}{l}\text { Resources } \\
\text { Geo-data downloading/ processing } \\
\text { infrastructure installed at LAPAN (National } \\
\text { Institute of Aeronautics and Space) } \\
\text { Data processing software installed at DG- } \\
\text { Planning } \\
\text { Data management system installed in } 18 \\
\text { computers at DG-Planning } \\
\text { Several trainings on RS and forest inventories } \\
\text { at national and subnational levels } \\
\text { Inadequate human and technical capacity at } \\
\text { subnational level }\end{array}$ & $\begin{array}{l}\text { Acquisition of higher resolution images and } \\
\text { advanced image analysis software } \\
\text { Increased international funding for forest } \\
\text { monitoring } \\
\text { Training of national and regional government } \\
\text { officials and nongovernmental actors on forest } \\
\text { carbon monitoring }\end{array}$ & $\begin{array}{l}\text { Acquisition of RS data and establishment of } \\
\text { permanent sample plots/temporary sample } \\
\text { plots } \\
\text { Budget for Forest Inventory and Monitoring } \\
\text { Budget for operationalization of NCMC } \\
\text { Training of district/village NR and } \\
\text { Environmental committees on forest carbon } \\
\text { monitoring }\end{array}$ \\
\hline $\begin{array}{l}\text { Legislations/ Procedures } \\
\text { Ministry of Forestry Regulation on Criteria } \\
\text { and Standards for Forest Inventories enacted } \\
\text { Presidential Decree on GHG Inventories } \\
\text { enacted } \\
\text { Ministry of Environment and Forestry } \\
\text { (MOEF) Regulation on establishment of } \\
\text { MoEF and on organization of MoEF enacted } \\
\text { Regulations outlines roles of different agencies } \\
\text { in REDD+ MRV } \\
\text { High "rule density," which creates confusion }\end{array}$ & $\begin{array}{l}\text { Forest and Wildlife Law adopted } \\
\text { Draft National Action Plan for Forest } \\
\text { Monitoring developed } \\
\text { Action Plan yet to be adopted } \\
\text { Both Law and Plan outline roles of different } \\
\text { actors in forest monitoring }\end{array}$ & $\begin{array}{l}\text { NCMC Project document details how agencies } \\
\text { will relate in MRV } \\
\text { Legislation to anchor NCMC and forest } \\
\text { monitoring in law yet to be enacted }\end{array}$ \\
\hline
\end{tabular}

Indonesian Carbon Accounting System (INCAS; INCAS 2013, Krisnawati et al. 2015b). Through INCAS, Indonesia has developed region-specific allometric equations (Krisnawati et al. 2012), methodologies for estimating GHG emissions from forests and peatlands (SNI 2011, Krisnawati et al. 2015a,c), and for processing satellite images (LAPAN 2014). Other strategies included piloting provincial/district-level forest monitoring in several provinces and districts across Indonesia (FORCLIME 2013a,b, UN REDD Programme 2013, RoI 2014a,b).

To implement forest monitoring for forest management in general and for REDD+ in particular, several national and subnational agencies have been (re)constituted. At the national level the
Directorate General of Forestry Planning and Environmental Management (henceforth DG Forest Planning), the Directorate of Forest Resources Inventory and Monitoring has been strengthened through technical capacity and infrastructure development (UN REDD Programme 2013). Additionally, a National Forest Monitoring System has been developed (Sugardiman 2012, RoI 2014b). At the newly established Directorate General of Climate Change, a Directorate of GHG Inventory and MRV has been established. Within this directorate, a subdirectorate of GHG Inventory and MRV of the land-based sector in general, and a section on GHG Inventory of the Forestry Sector in particular have been established (MoEF 2015, RoI 2015). At the subnational level, interviews and document analyses 
show that District MRV Task Forces have been established in several districts and provinces (UN REDD Programme 2013).

Indonesia has strengthened its technical and human resource capacity for forest monitoring. Through INCAS, a geo-data infrastructure has been installed at the National Institute of Aeronautics and Space (LAPAN) to facilitate downloading and processing of satellite images (INCAS 2013). Through recruitment and training, INCAS has built technical capacity within LAPAN to process satellite data. Interviews show that the DG Forest Planning has also developed software to support analyses of forest inventory data collected over the past 20 years. Through the UN REDD Program support, a specialized data management system for national forest inventories was installed in 18 computers at the DG Forest Planning, and 4 national and 18 provincial forest officers trained (UN REDD Programme 2013). Additionally, the DG Forest Planning has recruited 10 image interpreters at the national level and 22 at provincial technical units to fast-track land cover classification. At the subnational level, key agencies such as the Provincial Forest Service, Provincial Environment Service, Provincial Development Planning Agency, local universities, and local NGOs and REDD+ Project Developers have been trained on MRV (FORCLIME 2013a,b, Korhonen-Kurki et al. 2013, UN REDD Programme 2013, RoI 2014a,b).

To institutionalize GHG inventories and reporting in general, and monitoring and reporting of GHG emission reductions from REDD+ in particular, Indonesia has since 2005 enacted several pieces of legislation including presidential and ministerial regulations and procedures. The Presidential Degree No 71 on Implementation of National Greenhouse Gas Inventories (RoI 2011) outlines its aims as follows, provide information on emissions/reductions resulting from mitigation activities, and outlines the actors to be involved in GHG inventories. The Ministry of Forest Regulation No. 67 on criteria and standards for forest inventory (Ministry of Forestry 2006) also outlines which actors are responsible for forest inventories in which areas. Presidential Regulation No. 16 (2015) that establishes the Ministry of Environment and Forestry (MoEF; RoI 2015) and MoEF Regulation No. P. 18 (2015) on organization of work of the MoEF (MoEF 2015) further clarifies which directorates and subdirectories are responsible for what activities with regard to GHG Inventory in general and REDD+ MRV in particular. Additionally, key government agencies such as MoEF, National Institute of Aeronautics and Space, and Geospatial Information Agency have signed memoranda of understanding (MoU), which spells out the responsibility of each on issues of forest monitoring for REDD+.

However, assessment of institutionalization of MRV in Indonesia as deep needs to be put into perspective and nuanced in several ways. First, although new strategies have been developed, several interviews showed that some of these strategies, especially INCAS, are strongly contested. Arguments concern the methodologies and algorithms used in INCAS and their suitability to Indonesian conditions. Second, although Indonesia has built a considerable technical and human resource base for forest monitoring, these are not yet sufficient. Most interviewees observed that although there could be enough human capacity at the national level, this is still scattered across different agencies (see also Sugardiman 2012, UN REDD Programme 2013). A majority $(70 \%)$ also noted that technical capacity for forest carbon monitoring at the subnational level is very low. Third, issues of coordination among national agencies and between national and subnational agencies and nongovernmental actors remain problematic (see also Korhonen-Kurki et al. 2013, Steininger 2014) because some agencies are not open to sharing data. Finally, there is also what can be characterized as "rule density." As shown above, there are many regulations on GHG inventories in general and forest monitoring in particular. Many of the interviewees noted that inconsistencies among these regulations and procedures create confusion.

Intermediate-shallow institutionalization of $M R V$ in Peru In Peru, the extent of institutionalization of MRV can be assessed as shallow-intermediate, for different reasons. Institutionalization of MRV has evidently gone beyond shallow because MRV has materialized in an additional aim of forest monitoring: quantification of forest-cover change and associated $\mathrm{CO}_{2}$ emissions/removals (Piu and Menton 2014, RoP 2014, Steininger 2014). To realize this additional aim of forest monitoring, Peru has developed new strategies. These include implementation of a multipurpose national forest inventory (NFI; Ministerio de Agricultura and Ministerio del Ambiente 2011) and development of deforestation statistics for the entire country (Gonzáles et al. 2014, MINAM 2014a, Potapov et al. 2014), region-specific emission factors (MINAM 2014b), and methodologies for forest cover change mapping (MINAM and MINAGRI 2014a) and classifying satellite images (MINAM and MINAGRI 2014b). However, implementation of these strategies especially the NFI is yet to be completed, and emission factors for other regions have not been developed.

In terms of actors, new agencies to implement forest monitoring for REDD+ have been proposed (RoP 2014). The Draft National Action Plan for Forest Monitoring envisages the formation of several bodies to perform forest monitoring for REDD+. These include the Technical Task Force for Forest Monitoring comprising representatives from the Ministry of Environment, the National Forest and Wildlife Service (SERFOR), and the local office of the Amazon Cooperation Treaty Organization. A sixmember team comprising two representatives from each of these agencies has been constituted as the Interim Task Force. Additionally, the Ministry of Environment has assigned two staff members to oversee forest cover change analysis (Steininger 2014). Other envisaged bodies include the Executive Steering Committee, an intergovernmental group, a high-level advisory group, and the National Forest Monitoring Group (see RoP 2014). A new Directorate of Inventory and Evaluation has been established within SERFOR to institutionalize the ongoing NFI (MINAM 2015). However, interviewees noted that except for the new Directorate of Inventory and Evaluation and the Interim Task Force, all other envisaged bodies were yet to be constituted by late 2016 .

In terms of resources, Peru has mobilized new and additional resources for forest monitoring. At the Ministry of Environment, the Global Land Analysis and Dynamics system (Potapov et al. 2014, 2015) and technologies for image analysis such as CLASlite (Asner et al. 2009) have been installed to facilitate forest cover change monitoring. Several development cooperation agencies 
have together committed over US\$12 million for the development of REDD+ in Peru, and 10\% of this budget is for the design of the REDD+ MRV system (Ministerio de Agricultura and Ministerio del Ambiente 2011). The FAO-Finland cooperation has also committed USD 6 million for the NFI (Ministerio de Agricultura and Ministerio del Ambiente 2011). Interviewees noted that training sessions have been held to build capacity of local communities, regional and national government agencies, and NGOs on forest carbon monitoring (Robiglio et al. 2014, Steininger 2014). The interviewees also noted that some of the regional governments have been equipped with technologies for forest cover change monitoring and analysis.

In terms of rules, Peru is formulating new legislations and procedures to institutionalize forest monitoring in general and MRV in particular in law. The newly adopted Forest and Wildlife Law (Law Decree No. 29763) and its recently approved Regulations (Supreme Decree No. 21-2015) (MINAM 2015) identify SERFOR and the Ministry of Environment as the government agencies responsible for the performance and periodic update of national forest inventories. Additionally, the Draft National Action Plan for Forest Monitoring identifies the bodies that will be created to conduct forest monitoring for REDD+ and outlines their roles and their relation with one another. However, except for the Forest and Wildlife Law and its regulations that have been adopted (MINAM 2015), the Draft National Action Plan for Forest Monitoring has not been adopted. Yet, it is this Plan that outlines the additional aim of measuring forest carbon stocks and its changes, and the roles of different actors in MRV.

\section{Intermediate-deep institutionalization of MRV in Tanzania}

In Tanzania, institutionalization of MRV can be assessed as intermediate-deep, because MRV has materialized in three elements of the PAA. Like in the other countries, MRV has materialized in revised aims and scope of forest monitoring. These aims and scope have been reviewed to include measurement of forest carbon stocks and its changes (Hojas-Gascon and Hugh 2014, Kweka et al. 2015, NCMC Project Document 2015, URT 2015). To realize these revised aims, Tanzania has implemented several strategies including the National Forest Monitoring and Assessment of Tanzania Mainland (NAFORMA; URT 2015) and the Zanzibar Wood Biomass Survey (Indufor 2013a). The other strategy involved implementation of the project "Enhancing MRV of forests in Tanzania through the application of advanced remote sensing techniques" commonly called the "LiDAR project" that piloted use of LiDAR and other highresolution remote sensing technologies for forest carbon monitoring (MFA and URT 2011). Other strategies involved piloting community/participatory forest carbon monitoring under different REDD+ pilot projects (Indufor 2013b, Mäkelä 2015). Through these strategies, Tanzania has developed background forest cover data and allometric equations (URT 2015), manuals and methodologies for forest inventories (Tomppo et al. 2010b, URT 2010a), methodologies for socioeconomic surveys (URT 2010b), and a list of tree species names (URT $2010 c)$.

Like in Indonesia, new agencies have been established to implement MRV. First, at the national level, an MRV working group was established to deliberate on technical issues of forest monitoring. These deliberations led, second, to the establishment of the National Carbon Monitoring Centre (NCMC) (MFA and URT 2015). Third, within the Tanzania Forest Service, a Forest Monitoring and Inventory Section was established to institutionalize periodic national forest inventories. In addition, District and Village Natural Resource and Environmental Committees have been mobilized and strengthened to undertake forest monitoring (see below). This is different than in Peru where most of the bodies envisaged to perform forest monitoring for REDD+ are yet to be constituted.

As in Indonesia and Peru, Tanzania has mobilized a significant technical and human resource base for forest monitoring. Through the FAO-Finland and Norwegian cooperation, Tanzania has acquired several remote sensing and ground-based forest measurement equipment (FAO 2011, MFA and URT 2011, 2015, URT 2015). Interviews indicate that Tanzanian universities, especially Sokoine University of Agriculture (SUA), which hosts the NCMC, have been well equipped with GIS laboratories and image analyses software. Financially, the Norwegian Government has committed an equivalent of over US\$4 million to support the NCMC for the next three years (MFA and URT 2015). The FAOFinland cooperation has also committed almost US\$20,000 to facilitate institutionalization of NAFORMA within the Tanzania Forest Service (FAO 2011). Also, a government interviewee reported that the Tanzanian government has allocated an equivalent of US $\$ 400,000$ for the remeasurement of sample plots established under NAFORMA. Some 170 national and districtlevel forest officers have been trained and engaged in forest monitoring under NAFORMA (URT 2015). Local communities and district-level government officers have also been mobilized and trained on forest carbon monitoring.

In terms of rules however, no legislations have been developed to anchor forest monitoring in law. Although the NCMC project documents (NCMC Project Document 2015) outline the roles of different actors in MRV and how they will relate with the NCMC, no legislations have been enacted to formalize MRV in law. Furthermore, while the NCMC has been formalized in MoU between the Norwegian Embassy and the Department of Environment (DoE-VPO) and between the DoE-VPO and SUA, this has not been accompanied by a legislation that anchors the NCMC in law. This is unlike in Indonesia and Peru, where legislations have been developed to anchor forest monitoring in general and MRV in particular in law. Moreover, although the roles of the various actors in MRV have been clarified, interviews showed that many of these actors are not aware of their roles, and how these will relate with the NCMC. The REDD+ pilot projects, which formed part of Tanzania's readiness activities, have also ended (see Mäkelä 2015), leading what the interviews characterized as loss of institutional memory (Indufor 2013b).

\section{Exploring reasons for differences in institutionalization of MRV across countries}

The preceding section shows that MRV has reshaped and materialized in new and reformed institutions for forest monitoring in all three countries. However, it is also shows that the extent of institutionalization varies across countries, with Indonesia experiencing deep institutionalization, Peru shallowintermediate institutionalization, and Tanzania intermediatedeep institutionalization. The question addressed here is what factors could explain the differences across countries. 
First, discursive institutionalism identifies the "existential," "timeliness," and "resonance" of a discourse and its ideas as critical for institutionalization. This condition was present in Indonesia and Tanzania, but not in Peru. In both countries, MRV has been a topical national REDD+ policy issue since 2008 as both governmental and nongovernmental stakeholders have been concerned with how to measure and account for emission reductions. Indeed, the need to monitor forests and account for forest carbon has been advocated by a broader audience in Indonesia and Tanzania than in Peru. This audience comprises national government agencies (the former Ministries of Forestry and Environment and the defunct National Climate Change Council and National REDD+ Agency, for Indonesia; and the Forest and Beekeeping Division [FBD] and Department of Environment of the Vice President's Office [DoE-VPO], for Tanzania), and nongovernmental organizations (NGOs), project developers, and local communities implementing REDD+ pilot projects. Interviews showed that this audience has been concerned with how they could measure and account for the carbon stored in their forests or the carbon impacts of their REDD+ projects. Consequently, in Indonesia, several REDD+ pilot projects incorporated MRV in their activities and piloted subnational and project-level MRV implementation (UN REDD Programme 2013). In addition, several national and regional government agencies, NGOs, project developers, and the academia were represented in national REDD+ MRV policy discussions (Indonesian REDD+ Task Force 2012). Thus, despite some differences on strategic aspects such as the methods to use, interviews show that there was broad consensus, hence political support, on the need to reform the existing national forest inventory and create new agencies to specifically deal with GHG inventories in the land use (forests and peatlands) sector.

Similarly, in Tanzania, most of the REDD+ pilot projects incorporated MRV in their activities (Indufor 2013b). Additionally, the NGOs implementing these pilots were well represented in national MRV policy discussions (Rantala 2012) and introduced their ideas of how MRV should be conducted and how the different constituencies they represent could be engaged in the process (see REDD Pilot Projects 2011, Rantala and Di Gregorio 2014). In Peru, by contrast, although MRV has been a key REDD+ policy issue, national-level discussions on REDD+ in general (Piu and Menton 2014) and MRV in particular began only recently. Although the regional governments of the five regions that span the Peruvian Amazon, NGOs, project developers, and local communities had been discussing MRV in so-called REDD+ Roundtables (RoP 2011, CIF 2013) and piloting subnational and project level implementation of MRV since 2008 (see also Joseph et al. 2013), interviews show that national-level policy discussions on MRV remained limited until after 2012 (Piu and Menton 2014, RoP 2014, Kowler and Larson 2016). This suggests that for quite some time, MRV was not a topical policy issue at the national level and did not resonate with a larger audience in Peru.

Second, DI emphasizes the importance of credibility and coherence of a discourse in enabling institutionalization. The importance of this factor was particularly evidenced in Indonesia and Tanzania. In both countries, the interviews showed that MRV and the ideas it represents, especially that of involving local communities and other nonstate actors was well received by and appealing to a broader audience including national and subnational government agencies and nongovernmental actors. Consequently, inclusion of governmental and nongovernmental actors in forest monitoring for REDD+ was widely discussed and the roles of both in MRV agreed upon in a consensual manner. In Peru, by contrast, the idea of involving regional governments, local communities, and NGOs in MRV, while advocated by the latter (Robiglio et al. 2014), has not been appealing to national government agencies especially the Ministry of Environment. This can be seen in the fact that the Ministry has allocated only a "verification" role to regional governments, NGOs, and local communities (RoP 2014), a proposal that has not been well received by the latter. Conversely, according to confidential interviews, there has been limited credibility, and hence political support, of the proposed institutional changes among regional governments, NGOs, project developers, and local communities. Some interviewees argued that this explains why agencies proposed to implement MRV have not been constituted because their establishment does not enjoy the political support of this group.

Third, DI also emphasizes the importance of authoritative and sentient agencies in promoting discourse institutionalization. The importance of this factor was manifested in Indonesia and Tanzania. In both countries, the revision of the aims of forest monitoring and development of new strategies to implement MRV was advocated and supported by authoritative governmental and nongovernmental agencies. In Tanzania, all the key policy actors agreed on the need to establish the NCMC (Rantala and Di Gregorio 2014). Despite initial disagreements on where the NCMC should be hosted, a host institution was not only selected in a consensual manner, but interviews also showed that its establishment was advocated and supported by authoritative actors such as the Norwegian Embassy in Dar es Salaam, national government agencies such as FBD and DoEVPO, and influential NGOs such as the Tanzania Forest Conservation Group (for authority and influence of these actors see Rantala 2012 and Rantala and Di Gregorio 2014).

Similarly, in Indonesia, interviewees indicated that the need to reform the existing national forest monitoring system and create new agencies was advocated and spearheaded by the authoritative former Ministry of Forestry and the defunct National Climate Change Council and National REDD+ Agency (Brockhaus and Di Gregorio 2014, see Moeliono et al. 2014 for the relative authority and influence of these actors), and more recently by the newly established Directorate General of Climate Change. The establishment of the Directorate of GHG Inventory and MRV was also advocated for and supported by authoritative national government agencies including the Presidency and the powerful National Planning Agency (Indonesian REDD+ Task Force 2012). By contrast, in Peru the interviewees indicated that the various strategies proposed to implement REDD+ MRV have not enjoyed the support of some authoritative actors especially the regional governments who are the authorities in charge of forests in their respective regions, as well as nongovernmental actors.

Fourth, DI emphasizes the (political) popularity and encompassing nature of discourse as a critical factor for institutionalization. This factor was present in Indonesia and Tanzania but not in Peru. In both Indonesia and Tanzania, data 
from interviews show that MRV has been presented as an allinclusive activity that requires involvement of actors with different kinds of expertise, and both governmental and nongovernmental organizations. Consequently, both state agencies (including forestry and nonforestry agencies) as well as nongovernmental actors have been represented in national MRV policy discussions. This indicates that in both countries MRV has been considered to transcend the sphere of any specific actor. By contrast, in Peru, interviews show that MRV has been presented as a technical issue that can be discussed and performed by only a certain calibre of experts. As a result, national discussions on MRV have been restricted to a closed group of experts comprising the Ministries of Environment and Agriculture, the Amazon Cooperation Treaty Organization, and a select group of a few academicians and international agencies. This has meant that there is neither a broad-based national policy nor a broader societal discussion on MRV in Peru. Thus, the ideas presented in these technical expert discussions do not represent the views of a broader audience, but can be characterized as representing the language and sphere of only a small group of experts.

Last, discursive institutionalism also holds that for any new or counter discourse to institutionalize, the existing discourse and related institutions must be under pressure. Our findings show, however, that this is not as critical a condition as the first four already discussed. In all the three countries, national policy discourses on and institutions for forest monitoring have been under pressure to reform and accommodate emerging international demands for information and data on national forests. Indeed, as indicated above, in all the three countries, the aims of forest monitoring were reviewed to accommodate issues of carbon accounting and new strategies to implement the revised aims developed. However, because the other four conditions have not been met in Peru, institutionalization of MRV has not gone beyond shallow-intermediate. This is in contrast to Indonesia and Tanzania where all the other four factors were present to a considerable degree. The relatively shallow institutionalization of MRV in Tanzania compared to Indonesia is mainly because Tanzania has not developed new/revised legislations and procedures to anchor forest monitoring in law. This can be attributed to lack of involvement of high level policy makers (president, ministers) in Tanzania compared to Indonesia.

\section{DISCUSSION AND CONCLUSIONS}

We have sought to analyze and compare the extent of institutionalization of MRV in Indonesia, Peru, and Tanzania, and to explain any differences across the countries. The results showed that MRV has materialized in new and reformed institutions for forest monitoring in all countries. This finding puts into perspective the cynicism of many commentators on the willingness and capacity of (developing) countries to implement international agreements. Too often, developing countries are portrayed as signing international agreements to please donors without any intention of implementing such agreements (Young 1999, Dimitrov 2005, Humphreys 2006). However, as the findings of this study show, (some) developing countries take efforts to implement the international (environmental) agreements they sign. We do not claim that all necessary REDD+ elements have been institutionalized in the three countries. On the contrary, when the findings of this study are cast in the broader debates on progress with REDD+ implementation, it can be concluded that
MRV is the only REDD+ element that has progressed (cf. Korhonen-Kurki et al. 2013). Although all the studied countries have developed REDD+ strategies and are in the process of developing reference emission levels and safeguards, which are the other three elements of REDD+ (UNFCCC 2010), the REDD+ literature (e.g., Angelsen et al. 2012, Minang et al. 2014, Brockhaus et al. 2017) shows that none of the studied countries has addressed the drivers of deforestation and forest degradation that should be the main focus of REDD+.

However, our point here is that international agreements have influence on national organizations and institutions. As DI posits, these international agreements and the discourses and ideas associated with them influence national institutions in two steps. First, the discourses and ideas arising from the international agreements trigger national policy discussions on how to implement their provisions. Second, through these national discursive processes policy actors develop new or revised strategies to implement the provisions of the agreements, mobilize new actors and resources, and formulate new or revised rules. This is exactly what we have seen in the three countries. Our findings therefore confirm the analytical potential of discursive institutionalism in examining the nexus between global discourses and ideas and national institutions.

However, national level institutionalization of discourses and ideas arising from the international level does not follow a linear policy process whereby they are simply implemented. As exemplified by the shallow-intermediate institutionalization of MRV in Peru, developing national strategies to implement discourses and ideas arising from international agreements involve discursive struggles among different policy actors and interest groups (Kowler and Larson 2016, Ochieng 2017). Such struggles, as DI posits, can effectively hinder institutionalization. In Peru, it is precisely the discursive struggles among different levels of government and agencies of government that militates against deep institutionalization of MRV (Robiglio et al. 2014, Ochieng et al. 2016b, Ochieng 2017). Although not the explicit focus of this paper, such struggles show that analyzing the interactive policy process as suggested by DI could point out the actors involved in such policy processes and their ideas and identify their ideational points of convergence and divergence. It is suggested that for a better understanding of discourse institutionalization, a study of the discursive process could be undertaken. This would not only highlight which actors and ideas win or lose in a given policy process but could provide a starting point for mediating the ideational points of contest that hinder deep institutionalization. By conceiving discourse as both the interactive process by which policy actors exchange ideas during policy making and public deliberation and as the ideas represented in such discursive exchanges (Schmidt 2008, 2010), DI therefore offers a potent analytical framework for disentangling and mediating the struggles involved in policy processes.

The varied extent of institutionalization of MRV and the manifestation of factors for discourse institutionalization in Indonesia and Tanzania and not Peru both affirms the centrality of these factors in facilitating discourse institutionalization as DI claims (Phillips et al. 2004, Schmidt 2008, Buijs et al. 2014) and offers useful lessons for other countries grappling with how to 
implement MRV. First, as the Indonesian and Tanzanian cases indicate, it is imperative that national policy discussions on MRV are initiated when the issue is not only existential and timely but also resonates with a larger and concerned audience. Kingdon (1995) has coined the term "policy window" to describe the time when a policy issue is existential, timely, and resonates with a majority of policy actors and interest groups. The findings of this study suggest that national policy actors would be successful in pushing for deep institutionalization if they could identify or create such policy windows. This can be done by broadening the political support of proposed policy solutions (Mehta 2010) through targeted awareness creation, lobbying, and stakeholder mobilization. Second, in developing any new strategies to implement MRV, countries could consider formulating an allinclusive policy process (see also Brockhaus et al. 2014) that involves all the authoritative actors. Our findings suggest that when authoritative actors are absent from calls for change and not behind it, new demands such as MRV might not be institutionalized at all.

A third lesson relates to the use of an inclusive and appealing storyline (Schmidt 2001, Phillips et al. 2004, Buijs et al. 2014). In Indonesia and Tanzania, lead government agencies used the popular and attractive ideas in MRV such as that of involving local communities and NGOs strategically to generate broader acceptance of proposed strategies. In Peru, by contrast, the allocation of a less appealing verification role to regional governments, local communities, and NGOs/projects developers has diminished the appeal of the proposed strategies. Cox and Béland (2013) have coined the term "valence" to conceptualize ideas and storylines that have high level of emotional appeal and resonance. The emotional attractiveness of the idea of involving subnational governments, local communities, and NGOs, as the Indonesian and Tanzanian cases demonstrates, have indeed proved an appealing storyline to advocate for change in institutions for forest monitoring.

Overall, the study highlights that DI provides a powerful theoretical framework for analyzing how ideas and discourses from the international level shape national policy processes and institutions. Additionally, it shows that the extent of discourse institutionalization can be explained by examining the theoretical factors for discourse institutionalization and their manifestation in a given policy process. This also suggests that taking these factors into account could enhance deep institutional change. Specifically, policy actors would be most successful if they could enhance the resonance and appeal of their policy choices, involve key authoritative agencies, and strategically hinge their policy solutions on appealing storylines. However, though discursive institutionalism considers the credibility of existing discourses and related institutions as crucial for discourse institutionalization, our study shows that this is not always the case. This is not surprising because there are many cases in which existing discourses and related institutions are under pressure, but institutionalization of new or counter discourses and realization of institutional change remains elusive. This suggests that for deep institutional change to occur, the legitimacy of existing discourses and related institutions must not only be under pressure, but the new or counter discourses and ideas must also meet the other theoretical factors for discourse institutionalization. We do not claim to identify through the DI lens all factors that can explain and provide insights into why or why not a particular country makes progress with MRV. Indeed, the observed struggles among policy actors on the best strategies to implement MRV suggests that other factors may also be useful in explaining the observed differences. Factors such as bureaucratic politics and political culture (Allison and Halperin 1972) also play a role in efforts to institutionalize international discourses such as REDD+ MRV. Future analysis of MRV could explore how these factors affect institutionalization. However, we believe that taking a DI perspective provides a useful tool to structure national MRV policy discussions ex ante, and highlight constraints and opportunities for countries aiming to implement MRV ex post.

Responses to this article can be read online at: http://www.ecologyandsociety.org/issues/responses. php/9967

\section{Acknowledgments:}

This work is part of the Global Comparative Study on REDD+ (GCS REDD+), led by the Centre for International Forestry Research (CIFOR). The authors are grateful for the inputs and expertise shared by the many interviewees, partners, and collaborators involved in the study. Funding was provided by the Norwegian Agency for Development Cooperation (Grant No. QZA 12/0882); the Australian Agency for International Development (Grant No. 63560); the European Union (Grant No. DCIENV12011/269-520); the International Climate Initiative (IKI) of the German Federal Ministry for the Environment, Nature Conservation, Building and Nuclear Safety (BMUB) (Grant No. KI II 7-42206-6/75); the United Kingdom Department for International Development (Grant No. TF069018); and the CGIAR Research Program on Forests, Trees and Agroforestry (Grant No. TF No. 069018).

\section{LITERATURE CITED}

Alemayehu, N. A., B. Arts, and K. F. Wiersum. 2013. Historical development of forest policy in Ethiopia: trends of institutionalization and deinstitutionalization. Land Use Policy 32:186-196. http://dx.doi.org/10.1016/j.landusepol.2012.10.008

Allison, G. T., and M. H. Halperin. 1972. Bureaucratic politics: a paradigm and some policy implications. World Politics 24:40-79. http://dx.doi.org/10.2307/2010559

Angelsen, A., M. Brockhaus, W. D. Sunderlin, and L. V. Verchot. 2012. Analysing REDD+: challenges and choices. Center for International Forestry Research, Bogor, Indonesia.

Arnouts, R., M. van der Zouwen, and B. Arts. 2012. Analysing governance modes and shifts - governance arrangements in Dutch nature policy. Forest Policy and Economics 16:43-50. http://dx.doi. org/10.1016/j.forpol.2011.04.001

Arts, B., and M. Buizer. 2009. Forests, discourses, institutions: a discursive-institutional analysis of global forest governance. Forest Policy and Economics 11:340-347. http://dx.doi. org/10.1016/j.forpol.2008.10.004 
Arts, B., and J. Tatenhove. 2004. Policy and power: a conceptual framework between the 'old' and 'new' policy idioms. Policy Sciences 37:339-356. http://dx.doi.org/10.1007/s11077-005-0156-9

Arts, B., and P. Leroy, editors. 2006. Institutional dynamics in environmental governance. Springer, Dordrecht, The Netherlands. http://dx.doi.org/10.1007/1-4020-5079-8

Asner, G. P., D. E. Knapp, A. Balaji, and G. Paez-Acosta. 2009. Automated mapping of tropical deforestation and forest degradation: CLASlite. Journal of Applied Remote Sensing 3:033543-033524. http://dx.doi.org/10.1117/1.3223675

Brockhaus, M., and M. Di Gregorio. 2014. National REDD+ policy networks: from cooperation to conflict. Ecology and Society 19(4):14. http://dx.doi.org/10.5751/ES-06643-190414

Brockhaus, M., M. Di Gregorio, and R. Carmenta. 2014. REDD+ policy networks: exploring actors and power structures in an emerging policy domain. Ecology and Society 19(4):29. http://dx.doi.org/10.5751/ES-07098-190429

Brockhaus, M., K. Korhonen-Kurki, J. Sehring, M. Di Gregorio, S. Assembe-Mvondo, A. Babon, M. Bekele, M. F. Gebara, D. B. Khatri, H. Kambire, et al. 2017. REDD+, transformational change and the promise of performance-based payments: a qualitative comparative analysis. Climate Policy 17:708-730. http://dx.doi.org/10.1080/14693062.2016.1169392

Buijs, A., T. Mattijssen, and B. Arts. 2014. "The man, the administration and the counter-discourse": an analysis of the sudden turn in Dutch nature conservation policy. Land Use Policy 38:676-684. http://dx.doi.org/10.1016/j.landusepol.2014.01.010

Climate Investment Funds (CIF). 2013. FIP investment plan for Peru. FIP/SC.11/4/Rev.1. CIF, Washington, D.C., USA.

Cox, R. H., and D. Béland. 2013. Valence, policy ideas, and the rise of sustainability. Governance 26:307-328. http://dx.doi. org/10.1111/gove.12003

Crespy, A., and V. Schmidt. 2014. The clash of Titans: France, Germany and the discursive double game of EMU reform. Journal of European Public Policy 21:1085-1101. http://dx.doi. org/10.1080/13501763.2014.914629

den Besten, J. W., B. Arts, and P. Verkooijen. 2014. The evolution of REDD+: an analysis of discursive-institutional dynamics. Environmental Science \& Policy 35:40-48. http://dx.doi. org/10.1016/j.envsci.2013.03.009

Dimitrov, R. S. 2005. Hostage to norms: states, institutions and global forest politics. Global Environmental Politics 5:1-24. http:// dx.doi.org/10.1162/152638005774785499

Food and Agriculture Organization (FAO). 1993. Forest resources assessment 1990. Tropical countries. FAO, Rome, Italy.

Food and Agriculture Organization (FAO). 2011. National forest monitoring and assessment of Tanzania (NAFORMA)- GCP/ GLO/194/MUL: mid-term evaluation report. FAO, Rome, Italy.

Forests and Climate Change Programme (FORCLIME). $2013 a$. Support for reduced emissions from deforestation and forest degradation (REDD). FORCLIME TC Module Briefing Note No. 1. FORCLIME, Jakarta, Indonesia. [online] URL: http:// www.forclime.org/documents/Briefing $\% 20$ Note/English/BR $\% 201 \%$ 20-\%20REDD Eng.pdf
Forests and Climate Change Programme (FORCLIME). 2013b. Support for the setup of a district forest management information system (DFMIS). FORCLIME TC Module Briefing Note No. 8. FORCLIME, Jakarta, Indonesia. [online] URL: http://www. forclime.org/documents/Briefing $\% 20$ Note/English/BR $\% 208 \% 20$ \%20DFMIS_Eng.pdf

Freitas, J., Y. M. de Oliveira, M. A. Rosot, G. Gomide, and P. Mattos. 2010. Development of the national forest inventory of Brazil. Pages 89-96 in E. Tomppo, T. Gschwantner, M. Lawrence, and R. E. McRoberts, editors. National forest inventories. Pathways for common reporting. Springer, Heidelberg, Germany.

Gonzáles, C. V., E. R. Báez, D. C. Soto, V. E. Mendoza, A. C. U. Carbonel, R. G. Granados, and N. M. Durán. 2014. Protocolo de Clasificación de Pérdida de Cobertura en los Bosques Húmedos Amazónicos entre los años 2000-2011. Ministerio de Agricultura y Riego, Lima, Perú.

Grainger, A., and M. Obersteiner. 2011. A framework for structuring the global forest monitoring landscape in the REDD+ era. Environmental Science \& Policy 14:127-139. http://dx.doi. org/10.1016/j.envsci.2010.10.006

Hojas-Gascon, L., and E. Hugh. 2014. Developing methods for monitoring forests degradation in Tanzania using fine spatial resolution RapidEye data. Joint Research Centre, European Commission, Ispra, Italy.

Holmgren, P., and L.-G. Marklund. 2007. National forest monitoring systems: purposes, options and status. Pages 163-173 in P. H. Freer-Smith, M. S. J. Broadmeadow, and J. M. Lynch, editors. Forestry and climate change. CAB International, Wallingford, UK. http://dx.doi.org/10.1079/9781845932947.0163

Holmgren, P., L.-G. Marklund, M. Saket, and M. L. Wilkie. 2007. Forest monitoring and assessment for climate change reporting: partnerships, capacity building and delivery. Forest Resources Assessment Working Paper 142. FAO, Rome, Italy.

Humphreys, D. 2006. Logjam; deforestation and the crisis of global governance. Earthscan, London, UK.

Indonesian National Carbon Accounting System (INCAS). 2013. Factsheet: Indonesian national carbon accounting system (INCAS) program. INCAS, Jakarta, Indonesia.

Indonesian REDD+ Task Force. 2012. REDD+ national strategy. Indonesian REDD+ Task Force, Jakarta, Indonesia.

Indufor. 2013a. Zanzibar woody biomass survey: preparedness for REDD+ phase: biophysical inventory report. Revolutionary Government of Zanzibar, Zanzibar.

Indufor. 2013b. Mid-term review of the Norwegian funded MRV research project in Tanzania. Indufor Asia Pacific, Auckland City, New Zealand.

Joseph, S., M. Herold, W. D. Sunderlin, and L. V. Verchot. 2013. REDD+ readiness: early insights on monitoring, reporting and verification systems of project developers. Environmental Research Letters 8:034038. http://dx.doi.org/10.1088/1748-932618/3/034038

Kingdon, J. W. 1995. Agendas, alternatives, and public policies. Second edition. HarperCollins, New York, New York, USA. 
Korhonen-Kurki, K., M. Brockhaus, A. E. Duchelle, S. Atmadja, P. Thu Thuy, and L. Schofield. 2013. Multiple levels and multiple challenges for measurement, reporting and verification of REDD+. International Journal of the Commons 7(2):344-366. http://dx.doi.org/10.18352/ijc.372

Kowler, L. F., and A. M. Larson. 2016. Beyond the technical: the politics of developing the MRV system in Peru. Center for International Forestry Research, Bogor, Indonesia.

Krisnawati, H., W. C. Adinugroho, and R. Imanuddin. 2012. Monograph: allometric models for estimating tree biomass at various forest ecosystem types in Indonesia. Forestry Research and Development Agency, Research and Development Center for Conservation and Rehabilitation, Ministry of Forestry, Bogor, Indonesia.

Krisnawati, H., R. Imanuddin, W. C. Adinugroho, and S. Hutabarat. 2015a. Standardmethods for estimating greenhouse gas emissions for the forestry sector in Indonesia, Version 1. Research and Development Center for Conservation and Rehabilitation, Forestry Research and Development Agency, Bogor, Indonesia.

Krisnawati, H., R. Imanuddin, W. C. Adinugroho, and S. Hutabarat. 2015b. National inventory of greenhouse gas emissions and removals on Indonesia's forests and peatlands. Research, Development and Innovation Agency of the Ministry of Environment and Forestry, Bogor, Indonesia.

Krisnawati, H., R. Imanuddin, W. C. Adinugroho, and S. Hutabarat. 2015c. Standard methods for estimating greenhouse gas emissions from forests and peatlands in Indonesia, Version 2. Research, Development and Innovation Agency of the Ministry of Environment and Forestry, Bogor, Indonesia.

Kweka, D., R. Carmenta, M. Hyle, I. Mustalahti, T. Dokken, and M. Brockhaus. 2015. The context of REDD+ in Tanzania: drivers, agents and institutions. Center for International Forestry Research, Bogor, Indonesia.

LAPAN (National Institute of Aeronautics and Space). 2014. The remote sensing monitoring program of Indonesia's national carbon accounting system: methodology and products, Version 1. LAPANIndonesia-Australia Forest Carbon Partnership, Jakarta, Indonesia.

Lei, X., M. Tang, L. Hong, and Y. Lu. 2010. Development of China's national forest inventory. Pages 113-130 in E. Tomppo, T. Gschwantner, M. Lawrence, and R. E. McRoberts, editors. National forest inventories. Pathways for common reporting. Springer, Heidelberg, Germany.

Liefferink, D. 2006. The dynamics of policy arrangements: turning round the tetrahedron. Pages 45-68 in B. Arts and P. Leroy, editors. Institutional dynamics in environmental governance. Springer, Dordrecht, The Netherlands. http://dx.doi. org/10.1007/1-4020-5079-8 3

LTS International. 2013. Real-time evaluation of Norway's international climate and forest initiative contribution to measurement, reporting and verification. Report 5/2013. Norad, Oslo, Norway.

Lund, H. G. [date unknown]. National forest inventories and global resource assessments. Forests and Forest Plants Vol. I.
Mäkelä, M. 2015. Lessons learned from the implementation of REDD pilot projects in Tanzania. The Royal Norwegian Embassy in Tanzania, Dar es Salaam, Tanzania.

McRoberts, R. E., and E. O. Tomppo. 2007. Remote sensing support for national forest inventories. Remote Sensing of Environment 110:412-419. http://dx.doi.org/10.1016/j.rse.2006.09.034

Mehta, J. 2010. The varied roles of ideas in politics: from "whether" to "how." Pages 23-46 in D. Béland and R. H. Cox, editors. Ideas and politics in social science research. Oxford University Press, Oxford, UK. http://dx.doi.org/10.1093/acprof: oso/9780199736430.003.0002

MFA and URT (Ministry of Foreign Affairs, Norway and United Republic of Tanzania). 2011. Agreement between the Government of the United Republic of Tanzania and the Norwegian Ministry of Foreign Affairs regarding development cooperation concerning 'Enhancing the Measuring, Reporting and Verification (MRV) of forests in Tanzania through the application of advanced remote sensing techniques.' United Republic of Tanzania, Dar es Salaam, Tanzania.

MFA and URT (Ministry of Foreign Affairs, Norway and United Republic of Tanzania). 2015. Agreement between the Government of the United Republic of Tanzania and the Norwegian Ministry of Foreign Affairs regarding development cooperation concerning 'Establishing a National Carbon Monitoring Center in Tanzania.' United Republic of Tanzania, Dar es Salaam, Tanzania.

MINAM (Ministry of Environment). 2014a. Mapeo de Pérdida de Cobertura de Bosques Húmedos Amazónicos del Perú entre los años 2000-2011. Ministerio del Ambiente, Republic of Peru, Lima, Perú.

MINAM (Ministry of Environment). 2014b. Estimación de los contenidos de carbono de la biomasa 1240 aérea en los bosques de Perú. Programa Nacional de Conservación de Bosques para la Mitigación del Cambio Climático, Ministerio del Ambiente, Republic of Peru, Lima, Perú.

MINAM (Ministry of Environment). 2015. Peru's submission of a Forest Reference Emission Level (FREL) for reducing emissions from deforestation in the Peruvian Amazon. Submission of the Republic of Peru to the United Nations Framework Convention on Climate Change. Ministerio del Ambiente, Republic of Peru, Lima, Peru.

MINAM and MINAGRI (Ministry of Environment and Ministry of Agriculture and Irrigation). 2014a. Memoria Descriptiva del Mapa de Bosque/No Bosque año 2000 y Mapa de pérdida de los Bosques Húmedos Amazónicos del Perú 2000-2011. MINAM, Republic of Peru, Lima, Perú.

MINAM and MINAGRI (Ministry of Environment and Ministry of Agriculture and Irrigation). 2014b. Protocolo de clasificación de pérdida de cobertura en los bosques húmedos amazónicos 1250 entre los años 2000 y 2011. MINAM, Republic of Peru, Lima, Perú.

Minang, P. A., M. Van Noordwijk, L. A. Duguma, D. Alemagi, T. H. Do, F. Bernard, P. Agung, V. Robiglio, D. Catacutan, S. Suyanto, A. Armas, C. Silva Aguad, M. Feudjio, G. Galudra, R. Maryani, D. White, A. Widayati, E. Kahurani, S. Namirembe, and B. Leimona. 2014. REDD+ Readiness progress across 
countries: time for reconsideration. Climate Policy 14:685-708. http://dx.doi.org/10.1080/14693062.2014.905822

Ministerio de Agricultura, and Ministerio del Ambiente. 2011. Inventario Nacional Forestal y Manejo Forestal Sostenible del Perú ante el Cambio Climático. Ministerio de Agricultura, and Ministerio del Ambiente, Lima, Perú.

Ministry of Environment and Forestry (MoEF). 2015. Ministry of Environment and Forestry Regulation No. P.18/Menlhk-II/2015 on organization and work procedures of Ministry of Environment and Forestry. [English Translation]. MoEF, Jakarta, Indonesia.

Ministry of Forestry. 2006. Ministry of Forestry Regulation No. P.67/Menhut-II/2006 on Standard and Criteria for Forest Inventory. [English Translation]. Ministry of Forestry, Jakarta, Indonesia.

Moeliono, M., C. Gallemore, L. Santoso, M. Brockhaus, and M. Di Gregorio. 2014. Information networks and power: confronting the "wicked problem" of REDD+ in Indonesia. Ecology and Society 19(2):9. http://dx.doi.org/10.5751/ES-06300-190209

Mohren, G. M. J., H. Hasenauer, M. Köhl, and G. J. Nabuurs. 2012. Forest inventories for carbon change assessments. Current Opinion in Environmental Sustainability 4:686-695. http://dx.doi. org/10.1016/j.cosust.2012.10.002

National Carbon Monitoring Centre (NCMC) Project Document. 2015. Establishing a national carbon monitoring centre in Tanzania. A proposal presented to Royal Norwegian Embassy, Dar es Salaam, Tanzania.

Ochieng, R. M. 2017. The role of forests in climate change mitigation: a discursive institutional analysis of REDD+ $M R V$. Dissertation. Wageningen University and Research, Wageningen, The Netherlands. http://dx.doi.org/10.18174/412210

Ochieng, R. M., B. Art, I. J. Visseren-Hamakers, M. Brockhaus, and M. Herold. 2015. Influence of REDD+ MRV rules on institutional arrangements for forest measurements in developing countries: insights from Peru. Proceedings of the XIV WORLD FORESTRY CONGRESS. FAO, Durban, South Africa.

Ochieng, R. M., I. J. Visseren-Hamakers, B. Arts, M. Brockhaus, and M. Herold. 2016a. Institutional effectiveness of REDD+ MRV: countries progress in implementing technical guidelines and good governance requirements. Environmental Science \& Policy 61:42-52. http://dx.doi.org/10.1016/j.envsci.2016.03.018

Ochieng, R. M., I. J. Visseren-Hamakers, M. Brockhaus, L. F. Kowler, M. Herold, and B. Arts. 2016b. Historical development of institutional arrangements for forest monitoring and REDD + MRV in Peru: discursive-institutionalist perspectives. Forest Policy and Economics 71:52-59. http://dx.doi.org/10.1016/j. forpol.2016.07.007

Phillips, N., T. B. Lawrence, and C. Hardy. 2004. Discourse and institutions. Academy of Management Review 29:635-652.

Piu, H. C., and M. Menton. 2014. The context of REDD+ in Peru: drivers, agents and institutions. Center for International Forestry Research, Bogor, Indonesia.

Potapov, P. V., J. Dempewolf, Y. Talero, M. C. Hansen, S. V. Stehman, C. Vargas, E. J. Rojas, D. Castillo, E. Mendoza, A.
Calderón, R. Giudice, N. Malaga, and B. R. Zutta. 2014. National satellite-based humid tropical forest change assessment in Peru in support of REDD+ implementation. Environmental Research Letters 9:124012. http://dx.doi.org/10.1088/1748-9326/9/12/124012

Potapov, P. V., S. A. Turubanova, A. Tyukavina, A. M. Krylov, J. L. McCarty, V. C. Radeloff, and M. C. Hansen. 2015. Eastern Europe's forest cover dynamics from 1985 to 2012 quantified from the full Landsat archive. Remote Sensing of Environment 159:28-43. http://dx.doi.org/10.1016/j.rse.2014.11.027

Punch, K. F. 2005. Introduction to social research: quantitative and qualitative approaches. Second edition. Sage, London, UK.

Rantala, S. 2012. Knowledge and brokerage in REDD+ policy making: a policy networks analysis of the case of Tanzania. Sustainability Science Program Working Paper No. 2012-03 and CIFOR Working Paper. Harvard Kennedy School, Cambridge, Massachusetts, USA.

Rantala, S., and M. Di Gregorio. 2014. Multistakeholder environmental governance in action: REDD+ discourse coalitions in Tanzania. Ecology and Society 19(2):66. http://dx. doi.org/10.5751/ES-06536-190266

REDD Pilot Projects. 2011. Feedback on National REDD Strategy by TZ REDD Pilot Projects. Tanzania Natural Resource Forum, Arusha, Tanzania.

Republic of Indonesia (RoI). 2011. Presidential Regulation No 71/2011 on implementation of national greenhouse gases inventory. [English Translation]. Republic of Indonesia, Jakarta, Indonesia.

Republic of Indonesia (RoI). 2014a. Indonesia district level $R E D D+$ emission reductions program. Republic of Indonesia, Jakarta, Indonesia.

Republic of Indonesia (RoI). 2014b. Updated mid-term progress report of the Republic of Indonesia and request for additional funding from the forest carbon partnership facility (FCPF). Republic of Indonesia, Jakarta, Indonesia.

Republic of Indonesia (RoI). 2015. Presidential Regulation Number 16 (2015) on establishment of the Ministry of Environment and Forestry. [English Translation]. Republic of Indonesia, Jakarta, Indonesia.

Republic of Peru (RoP). 2011. Readiness preparation proposal ( $R$ $P P)$. Ministry of Environment, Republic of Peru, Lima, Peru.

Republic of Peru (RoP). 2014. Emission reductions from deforestation fronts in the Peruvian Amazon. National Forest Conservation And Climate Change Mitigation Program (PNCBMCC) - Ministry of Environment, Republic of Peru, Lima, Peru.

Robiglio, V., A. D. Armas, C. Silva Aguad, and D. White. 2014. Beyond REDD+ readiness: land-use governance to reduce deforestation in Peru. Climate Policy 14:734-747. http://dx.doi. org/10.1080/14693062.2014.962467

Romijn, E., M. Herold, L. Kooistra, D. Murdiyarso, and L. Verchot. 2012. Assessing capacities of non-Annex I countries for national forest monitoring in the context of REDD+. Environmental Science \& Policy 19-20:33-48. http://dx.doi. org/10.1016/j.envsci.2012.01.005 
Romijn, E., C. B. Lantican, M. Herold, E. Lindquist, R. Ochieng, A. Wijaya, D. Murdiyarso, and L. Verchot. 2015. Assessing change in national forest monitoring capacities of 99 tropical countries. Forest Ecology and Management 352:109-123. http:// dx.doi.org/10.1016/j.foreco.2015.06.003

Schmidt, V. A. 2001. The politics of economic adjustment in France and Britain: when does discourse matter? Journal of European Public Policy 8:247-264. http://dx.doi.org/10.1080/135$\underline{01760110041578}$

Schmidt, V. A. 2008. Discursive institutionalism: the explanatory power of ideas and discourse. Annual Review of Political Science 11:303-326. http://dx.doi.org/10.1146/annurev.polisci.11.060606.135342

Schmidt, V. A. 2010. Taking ideas and discourse seriously: explaining change through discursive institutionalism as the fourth 'new institutionalism.' European Political Science Review 2:1-25. http://dx.doi.org/10.1017/S175577390999021X

Schmidt, V. A., and C. M. Radaelli. 2004. Policy change and discourse in Europe: conceptual and methodological issues. West European Politics 27:183-210. http://dx.doi.org/10.1080/014023$\underline{8042000214874}$

SNI (Indonesian Standardization Agency). 2011. Pengukuran dan penghitungan cadangan karbon - Pengukuran lapangan untuk penaksiran cadangan karbon hutan [Tranlation: Ground based forest carbon accounting]. SNI, Jakarta, Indonesia.

Steininger, M. 2014. Experiences in capacity building on forest monitoring at the national level: the FCMC Peru MRV Activity. USAID-supported Forest Carbon, Markets and Communities Program, Washington, D.C., USA.

Sugardiman, R. A. 2012. Stepwise approaches to developing REDD+ MRV capacity in Indonesia. Pages 27-39 in B. Mora, M. Herold, V. De Sy, A. Wijaya, L. Verchot, and J. Penman, editors. Capacity development in national forest monitoring: experiences and progress for REDD+. Joint report by CIFOR and GOFCGOLD, Bogor, Indonesia.

Tomppo, E., T. Gschwantner, M. Lawrence, and R. E. McRoberts, editors. 2010a. National forest inventories: pathways for common reporting. Springer, Heidelberg, Germany. http://dx.doi. org/10.1007/978-90-481-3233-1

Tomppo, E., M. Katila, K. Mäkisara, J. Peräsaari, R. Malimbwi, N. Chamuya, J. Otieno, S. Dalsgaard, and M. Leppänen. $2010 b$. Report to the Food and Agriculture Organization of the United Nations (FAO) in support of sampling study for national forestry resources monitoring and assessment (NAFORMA) in Tanzania. NAFORMA, Dar es Salaam, Tanzania.

United Nations Framework Convention on Climate Change (UNFCCC). 2009. Methodological guidance for activities relating to reducing emissions from deforestation and forest degradation and the role of conservation, sustainable management of forests and enhancement of forest carbon stocks in developing countries. UNFCCC Decision COP 15/4, Copenhagen, Denmark.

United Nations Framework Convention on Climate Change (UNFCCC). 2010. Outcome of the work of the Ad Hoc Working Group on long-term Cooperative Action under the ConventionPolicy approaches and positive incentives on issues relating to reducing emissions from deforestation and forest degradation in developing countries; and the role of conservation, sustainable management of forests and enhancement of forest carbon stocks in developing countries. UNFCCC COP 16, Cancun, Mexico.

UN REDD Programme. 2013. Final evaluation of the UN-REDD Programme in Iindonesia. UN REDD Programme, Jakarta, Indonesia.

United Republic of Tanzania (URT). 2010a. National forestry resources monitoring and assessment of Tanzania (NAFORMA): field manual, biophysical survey. Forest and Beekeeping Division, United Republic of Tanzania, Dar es Salaam, Tanzania.

United Republic of Tanzania (URT). 2010b. National forestry resources monitoring and assessment of Tanzania (NAFORMA): field manual socioeconomic survey. Forest and Beekeeping Division, United Republic of Tanzania, Dar es Salaam, Tanzania.

United Republic of Tanzania (URT). 2010c. National forestry resources monitoring and assessment of Tanzania (NAFORMA): Species List sorted by Latin names. Forest and Beekeeping Division, United Republic of Tanzania, Dar es Salaam, Tanzania.

United Republic of Tanzania (URT). 2015. National forest monitoring and assessment of Tanzania: main results. Tanzania Forest Service, Ministry of Natural Resources and Tourism, United Republic of Tanzania, Dar es Salam.

Van Tatenhove, J., B. Arts, and P. Leroy, editors. 2000. Political modernisation and the environment. The renewal of environmental policy arrangements. Kluwer Academic, Dordrecht, The Netherlands. http://dx.doi.org/10.1007/978-94-015-9524-7

Wiering, M. A., and B. J. M. Arts. 2006. Discursive shifts in Dutch river management: 'deep' institutional change or adaptation strategy? Hydrobiologia 565:327-338. http://dx.doi.org/10.1007/ s10750-005-5923-2

Young, O. R. 1999. The effectiveness of international environmental regimes: causal connections and behavioral mechanisms. MIT Press, Cambridge, Massachusetts, USA. 